\title{
The School Adaptation Process of Imprisoned Parents' Children
}

\author{
Serhat ARSLAN ${ }^{1}$, Serap KAZAN OĞUZ²
}

\begin{tabular}{l} 
ARTICLE INFO \\
\hline Article History: \\
Received 01.09.2019 \\
Received in revised form \\
05.02 .2020 \\
Accepted \\
Available online 01.03 .2020
\end{tabular}

INTRODUCTION

General Directorate of Prisons and Detention Houses clarifies that total number of prisoners in our country was 49.512 at the end of 2000, and this number increased to 228.993 in October 2017, approximately four (4.62) times in 17 years. The number of female prisoners increased faster and increased from 1,815 to 9985 in 17 years and increased approximately five (5.50) times. The General Directorate of Prisons and Detention Houses report that there are 389 penal institutions in our country with a capacity of 210.882. According to these data, it is estimated that at least 120 thousand children in our country expect to reach their mother or father in prison, but the numbers are estimates since there is no official statistics regarding the number of children whose mother or father is in prison (www.cte.adalet.gov.tr, 2018). Although prisoners are considered as lonely individuals who is disconnected from family and social ties and pushed out of society, the truth is different from this assumption. They have children, spouses, parents, siblings, in short, they have relatives who are affected by their convictions (Merçil, 2018). The conviction process has negative effects also on prisoners' relatives who are outside the prison. According to Caroline Touraut (2012), the "prisoner's family" statute is often associated with a lack of education, intellectual weakness, and danger. Prison experience crosses the walls and affects prisoners' relatives. Touraut defines this situation as "extended prison experience". The imprisonment process affects not only prisoner but also family and the prisoner leaves a family waiting for him and his children, if any (Murray, Farrington, \& Sekol, 2012).Convicted parents' children should be seen as "direct" victims of imprisonment rather than "secondary" victims (Transferring from Mitrani, Merçil, 2018). The difficulties faced by the children of prisoners began to be revealed by political actors and researchers at the end of the 20th century (Ayre, Gampell and Scharff-Smith, 2011). Those who experience the imprisonment of their relatives are afraid of being tagged and excluded by their friends, social circles. Relatives of prisoners state that they resort to common strategies such as not giving information and hiding secrets in order not to experience being tagged (Transferring from Saunders, Merçil, 2018). The implications of the prison process on the family are categorized as economic effects, changes in family relationships and quality, health problems (physical or mental), effects on school relationships and education life, social discrimination and inequality (Condry, R. \& Smith, P. S. 2018). Family structure deterioration or having a family member who has a negative personality reflects the children and causes them to be problematic individuals. According to the findings of the research carried out on 214 convicted youth which deals with Intelligence, Personality and Near Environment Characteristics of Offenders; among the first-degree relatives of the guilty youth, $54 \%$ convicted offenders were found (Dam, H, 2019). Prisoners' children face many problems, including imprisonment of parents and impaired family relationships, poverty, low academic performance, aggression, depression, guilt, and drug addiction

1Sakarya University,serhatarslan@sakarya.edu.tr,orcid.org/0000-0003-4422-8421

2Ministry of Education,Turkey, serapoguz89@gmail.com, orcid.org/0000-0002-8008-6267 
(www.childwelfare.gov). While numbers of campaigns and studies are carried out in Europe like "not my sentence still my sentence" which aims to facilitate prisoners' children's adaptation to life, in Turkey, there is no concrete project carried out for prisoners' children who are in a disadvantaged position in many ways apart from"Pending Child" project of the Civil Society Dialogue conducted with the approval of the Ministry of Justice, Reautonomy Foundation (TCYOV) executed by the Children of Prisoners Europe (COPE) partnership, Teachers Academy Foundation (ÖRAV) and Istanbul Gelisim University School of Health Sciences Social Service Department. In this study, it was aimed to identify the problems experienced by convicted family children as hidden and neglected victims, during the school adaptation process.

\section{Situation of the Problem}

The children whose mothers or fathers are in prison may face problems such as fear, embarrassment, exclusion, and feelings of guilt as well as longing for their parents. With their parents' imprisonment, these children witness all stages of the judicial process, witness their parents' arrest, as a result, they may have serious problems in adapting to school life. As a result of the student recognition questionnaire I applied, it is seen that there are 57 students whose parents are in prison. This data shows that 1 out of 27 students in our institution is convicted parent's children. In addition, it has been observed that this number is increasing gradually in schools in our neighborhood. While this is the case, it is important to investigate problems experienced by the students in the school adaptation process.

\section{Aim of the Study}

Aim of the present study is to determine problems experienced by the students in the school adaptation process. Within the framework of this general aim, answers to the following questions have been sought:

What is the perspective of prisoners' children on school?

What are their opinions about if this situation is known by teachers or friends?

What are the problems experienced by prisoners' children about their adaptation to school?

What are the methods of dealing with the situation they are in?

Are they able to get enough support from schools and teachers in this regard?

\section{METHOD}

In this study, interview technique, one of the qualitative research methods, was used. A semi-structured interview form was prepared by me for the research. Five open-ended questions were asked in the interview form. The students 'point of view to the school, and the questions like whether teachers or friends know about this situation and what happens if they learn, what their attitudes will be like, what problems they have in the process of adaptation to school, what are the methods of coping with this situation, how much their teachers' support is sufficient were asked. In the study, 10 students, whose mother or father is in prison, studying in Keçiören Özkent Akbilek Secondary School, have been reached with the purposeful sampling method. 7 students are male and 3 are female. The interviews with the students were carried out in the form of writing the answers and face to face interviews with their permission. The data obtained were analyzed by descriptive analysis method. A thematic framework was specified by me for the analysis of the data. Codes are created for each theme. The codes are specified as G1, G2, G3 for the students interviewed.

It was assumed that the students interviewed in the research answered the interview questions sincerely.

The research is limited to 10 students who were interviewed one by one and the questions were asked during the interview regarding the adaptation process of prisoners' children.

\section{FINDINGS}

According to the opinions of the convicted family children about the school adaptation process, tables were created and shown below. The views of prisoners' children on their perspective on school are shown in table 1. 
Table 1. Perspective of children of prisoners on school

\begin{tabular}{|c|c|c|c|}
\hline $\begin{array}{l}\text { Theme } \\
\text { (Categories) }\end{array}$ & Codes & $\mathrm{N}$ & $\%$ \\
\hline $\begin{array}{l}\text { Point of View to } \\
\text { School }\end{array}$ & $\begin{array}{l}\text { I love }(\mathrm{G} 2, \mathrm{~g} 3 \mathrm{~g} 5, \mathrm{~g} 6, \mathrm{~g} 7, \mathrm{~g} 9) \\
\text { Escape place to forget }(\mathrm{G} 1, \mathrm{~g} 3,) \\
\text { Because the mother/ father wanted }(\mathrm{G} 1, \mathrm{~g} 4) \\
\text { Peaceful(G3) } \\
\text { Liberation(G8) } \\
\text { To get a job(G10) } \\
\text { Way to save the mother (G10) } \\
\text { Not to stay at home (G9) }\end{array}$ & $\begin{array}{l}6 \\
2 \\
2 \\
1 \\
1 \\
1 \\
1 \\
1\end{array}$ & $\begin{array}{l}60 \\
20 \\
20 \\
10 \\
10 \\
10 \\
10 \\
10\end{array}$ \\
\hline
\end{tabular}

When Table 1 is examined, it is seen that the convicted family children love to come to school with a rate of $60 \%$ at most. Other opinions, respectively, are the escape place to forget what happened by $20 \%, 20 \%$ because the mother or father wanted, $10 \%$ peaceful, $10 \%$ as the only salvation, $10 \%$ to save the mother, $10 \%$ reported that they came to school in order not to stay at home. One-to-one quotes from student interviews are presented below.

"Actually, I don't want to come to school, but my father says study your lessons. I am coming for him, so that he will not be upset". (G4)

"Salvation. Just salvation. My only is school." (G8)

"Now I look positively, since I will not sell drugs like my mother like my father, the only way is to read. It is enough for me to be my profession. "(G10) 
Table 2. Opinions of prisoners' children if this situation is known by teachers or friends

\begin{tabular}{llll}
\hline $\begin{array}{l}\text { Theme } \\
\text { (Categories) }\end{array}$ & Codes & N $\%$
\end{tabular}

(Categories)

Friends shouldn't know (G1, g3, g4, g5, g6, g7, g8, g9, g10)

Teachers can know (G2, g3, g5, g6, g7, g9) $\quad 6 \quad 60$

Teachers shouldn't know (G1, g4, g8, g10) 440

Friends can know (G2) $\quad 1 \quad 10$

\author{
Being konown \\ by teachers or \\ friends
}

Possible

experience if they know

$\begin{array}{lll}\text { They make fun (G4, g6, g7, g8, g9) } & 5 & 50 \\ \text { They see me as criminal (G1, g3, g9, g10) } & 4 & 40 \\ \text { They pity on (G1, g5, g8) } & 3 & 30 \\ \text { They exclude (G5, g7, ) } & 2 & 20\end{array}$

When Table 2 is examined, it is stated that $90 \%$ of the friends should not know about the fact that their parents are in prison by their teachers or friends. Other opinions are $60 \%$ of teachers should know, and $10 \%$ of friends should have opinions. Their opinions about what will happen if the teacher or his friends know about it are $50 \%$ mocked, $40 \%$ guilty, 30\% pain, $20 \%$ excluded. One-to-one quotes from students' opinions are presented below.

"I don't want my teachers to know because they also tell my friends. They also pity me because my situation is bad, and think that I have a bad family."(G1)

"They make fun, they act as if I killed a man." (G9)

"They look like I'm guilty." (G10) 
Table 3: Views of prisoners's children on their problems they faced in school life

\begin{tabular}{llll}
\hline $\begin{array}{l}\text { Theme } \\
\text { (Categories) }\end{array}$ & Codes & N $\%$
\end{tabular}

$\begin{array}{lll}\text { Talking less (G1, g3, g6, g10) } & 4 & 40 \\ \text { Inability to focus(G5, g6, g9) } & 3 & 30 \\ \text { Not affected (G2, g7) } & 2 & 20\end{array}$

\title{
Problems lived in school life
}

\author{
$\begin{array}{lll}\text { Absenteeism increase (G1, g4) } & 2 & 20\end{array}$ \\ Feeling of guilt (G4) \\ $\begin{array}{lll}\text { Being quarrelsome (G1) } & 1 & 10\end{array}$ \\ Not being understood by teachers or friends \\ Giving up dreams (G9) $\quad 1 \quad 10$
}

When Table 3 is analyzed, it is seen that the problems students experience during school adaptation is $40 \%$ of talking less. While $30 \%$ of the students interviewed reported having a problem of focusing, $20 \%$ of students were stated to be unaffected by this situation. Other problems include an increase of $20 \%$ absenteeism, 10\% quarrels, $10 \%$ feelings of guilt, 10\% thinking cannot be understood by teachers or friends, and $10 \%$ giving up dreams. One-to-one quotes from students' opinions are presented below.

"I am angry against my father. I'm more introvert because of him. I feel absence, fatherlessness, absence of love. I want to talk less, I want to laugh a little. "(G3)

"I also think that nobody is trying understand me." (G8)

"I have no dreams, of course. The killer's daughter will not be a neurosurgeon. Funny ... "(G9)

Opinions of prisoners' children on how to deal with this process are presented in table 4 . 
Table 4. Opinions of prisoners' children on how to deal with this process

$\begin{array}{lll}\text { Theme (Categories) } & \text { Codes } & \mathbf{N} \\ \begin{array}{l}\text { Methods of dealing } \\ \text { with this process }\end{array} & & \\ & & \\ & \text { Wrangling (G1, g5) } & 2 \\ & \text { Thinking some fine day he/she will come (G4, g6) } & 20 \\ & \text { Talking to nobody (G3, g6) } & 2 \\ & \text { Disregarding (G2, g7) } & 20 \\ & \text { Trying to forget(G1) } & 2 \\ & \text { Trying to recover(G8) } & 1 \\ & \text { Writing letters (G9) } & 1 \\ & \text { Standing strong for brother/sister(G10) } & 10 \\ & & 1 \\ & & 10 \\ & & 10\end{array}$

When Table 4 is examined, it is seemed that while the responses to fight, ignore, not talk to anyone and wait for the day to come are $20 \%$, the interviewed students try to forget $10 \%$, try to recover $10 \%$, write a letter $10 \%$ and fight for brother/sister10\% . One-to-one quotes from students' opinions are presented below.

"I'm angry and contentious. I can't take my ambition. I constantly quarrel with someone. I'm trying to forget. "(G1)

"I was writing a letter. I was saying what I thought of. I was writing a letter to my father. "(G9)

"... living for my brother. I try to endure." (G10)

The views of prisoners' children on support from the school during this period are presented in table 5.

Table 5: Views of prisoners' children on the support from the school in this process

\begin{tabular}{|c|c|c|c|}
\hline $\begin{array}{l}\text { Theme } \\
\text { (Categories) }\end{array}$ & Codes & $\mathbf{N}$ & $\%$ \\
\hline
\end{tabular}

$\begin{array}{llll} & \begin{array}{l}\text { I didn't get enough support (G1, g2, g5, g8, g10) } \\ \text { They were supportive enough (G3, g4, g6, g7, g5) }\end{array} & 5 & 50 \\ \begin{array}{l}\text { Support from } \\ \text { the school }\end{array} & \text { They } & 5 & 50\end{array}$


When Table 5 is examined, $50 \%$ of the students interviewed think that they do not get enough support from their teachers, while 50\% report that they receive enough support from the school. One-to-one quotes from students' opinions are presented below.

"No. They just get angry. "(G1)

"Yes. My teacher always take cares of me. I am also talking to the guidance teacher. My mom comes to school all the time. "(G3)

"No way. Just my teacher asked if I need financial support. But I wish I could be like a friend and let me open up to him. "(G5)

\section{RESULT, DISCUSSION, AND SUGGESTION}

The results reached in the research conducted to obtain the opinions of the students who have at least one of their parents in prison about the school adaptation processes can be summarized as follows:

1. It was observed that convicted family children came to school with a rate of $60 \%$ regarding their opinions about the school. Other opinions, respectively, are the escape place to forget what happened by $20 \%, 20 \%$ because the mother or father wanted, $10 \%$ peaceful, $10 \%$ as the only salvation, $10 \%$ to save the mother, $10 \%$ was observed that they came to school in order not to stay at home.

2. $90 \%$ of the friends should not know about the fact that their parents are in prison by their teachers or friends. Other opinions are $60 \%$ of teachers should know, and $10 \%$ of friends should have opinions. Their opinions about what will happen if the teacher or his friends know about it are 50\% mocked, $40 \%$ guilty, $30 \%$ pain, $20 \%$ excluded.

3. The problems students experience during school adaptation is $40 \%$ of talking less. While $30 \%$ of the students interviewed reported having a problem of focusing, $20 \%$ of students were stated to be unaffected by this situation. Other problems include an increase of $20 \%$ absenteeism, $10 \%$ quarrels, $10 \%$ feelings of guilt, $10 \%$ thinking cannot be understood by teachers or friends, and $10 \%$ giving up dreams.

4. When the methods they applied to compete with this situation are examined, it is seemed that while the responses to fight, ignore, not talk to anyone and wait for the day to come are $20 \%$, the interviewed students try to forget $10 \%$, try to recover $10 \%$, write a letter $10 \%$ and fight for brother/sister $10 \%$.

5. The convicted family children reported that they did not get enough support from their teachers at the rate of $50 \%$ regarding the question of whether they had sufficient support from their teachers, and $50 \%$ reported that they received sufficient support from the school.

According to the results of the research, it has been seen that the children of prisoner parents encounter many problems in adapting to school. Although the majority of the convicted family children interviewed stated that they came to school with love, they are afraid that their situation will be heard by their friends or teachers. They believe that if it is known, negative situations such as mocking, exclusion, being seen guilty and suffering may occur. As a result of the interviews, it is clearly seen that the students prefer to speak much less than before and have focusing problems, and as a result of this situation, it is concluded that they exhibit more vicious behaviors. It is understood that the convicted family children need to express themselves comfortably rather than the questions about whether there is a financial problem.

As a result of the interviews, it is seen that the problems children have in their family, complicate the adaptation process and cause various problems (Duman \& Karagöz, 2016; Karagöz, 2016). Expressing that no institution can replace family and give the child what a family can give, Büyükkaragöz (1990) 
emphasizes the importance of the mother and father in the development of the child by stating that the role of the family in the child's incompliance to school is very serious.

Ylldırım (2004), who describes the events that occur in the lives of individuals like stress, irritation and challenges as "daily troubles". He emphasizes that these daily problems cause the students' work to deteriorate and their school lives to be boring or to have breaks. As a result of these problems experienced by prisoners' children it is clearly seen that they have difficulties in adapting to school and not being able to focus. According to the research findings, the prison process not only affects the prisoner but also the relatives. Merçil (2018) In his work, titled "Inner" and "Outside", it is emphasized that prisoners have to face physical, moral and social problems by affecting the psychological and physical health, education, private and professional lives of the prisoners' relatives, as well as prisoners. He said that it makes them feel worthless and guilty.

It was clearly stated that the convicted family children were sensitive to this situation not being heard. They state that they try to hide this situation by thinking that they will face negative attitudes such as exclusion, mocking, seen as criminals, and pity. Convicted parents' children may experience fear, embarrassment, social isolation or labeling, have to deal with a number of difficulties that put their development at risk, and face other risks of discrimination, social exclusion and poverty in social life, like other disadvantaged children. With the imprisonment process, children also meet the prison and justice system, and they are deprived of parental attachment due to their uncertainty and instability. In most cases, they witness the arrest of their parents and they are exposed to bullying / exclusion at school and in society due to this sensitive situation (https://childrenofprisoners.eu) .

800,000 children each year in the European Union countries and 2.7 million children in the United States are separated from their parents as a result of imprisonment. (https://childrenofprisoners.eu ). In our country, it is estimated that at least 120 thousand children expect to rejoin their mother or father in prison, but the numbers are estimates since there is no official statistics regarding the number of children whose mother or father is in prison. As seen in the data, the prisoner parents' children who are seen as secondary victims are non-negligibly high. While this is the case, it is inevitable to work on the problems these children face during the school adaptation process. It is beneficial to conduct studies in order to determine the numbers of prisoners' children clearly and to enable these children to overcome this process in a healthy way.

\section{REFERENCES}

Büyükkaragöz, S. (1990). Okula uyumsuzluk ve başarısızlıkta ailenin rolü. Ĕ̆itim ve Bilim, 14(78). Codd, H. (2007). Prisoners' families and resettlement: A critical analysis. The Howard Journal of Criminal Justice, 46(3), 255-263.

Condry, R., Smith, P.S. (2018). The sociology of punishment and the effects of imprisonment on familie. Prisons, Punishment, and the Family: Towards a New Sociology of Punishment.

Dam, H. (2009). Öğrencinin okul başarısında aile faktörü. Hitit Üniversitesi İlahiyat Fakültesi Dergisi, 7(4).

Duman,T. \& Karagöz,S (2016). An evaluation of Turkish teacher education system compared to other models in different countries. International Journal of Educational Research Review, 1 (1), 1-13.

Gampell, L., \& Scharff-Smith, P. (2011). Children of imprisoned parents. Jes Ellehauge Hansen. Denmark.

Karagöz,S. (2016). Opinions and suggestions regarding various subjects on the educational guidance in the second constitutional era. Journal of Family, Counseling and Education, 1 (1), 1-9.

Larman, G., \& Aungles, A. (1991). Children of prisoners and their outside carers: the invisible population. Women and the Law. Easteal, Patricia Weiser \& McKillop, Sandra (eds). Australian Institute of Criminology: Canberra.

Merçil, İ. (2018). İçerisi ile dişarisi arasinda mahpus yakinlari. MSGSÜ Sosyal Bilimler, 18,374-411.

Morgan, J., Leeson, C., Dillon, R.C., Wirgman, A.L., Needham, M. (2014). A hidden group of children: Support in schools for children who experience parental imprisonment. Children \& Society, 28(4).

Murray, J., Farrington, D. P., \& Sekol, I. (2012). Children's antisocial behavior, mental health, drug use, and educational performance after parental incarceration: A systematic review and meta-analysis. Psychological bulletin, 138(2), 175.

Saunders, V. (2018). What does your dad do for a living? Children of prisoners and their experiences of stigma. Children and Youth Services Review, 90, 21-27. 
Arslan,S. \& Kazan Oğuz, S. (2020). The school adaptation process of imprisoned parents' children. International Journal of Educational Research Review, $5(2), 126-134$.

https://cttre.adalet.gov.tr

https:/childrenofprisoners.eu/wp-content/uploads/2017/04/Mahpus-Anne-Babalar-ve-\%C3\%87ocuklariImprisoned-parents-and-children-good-practice-guide.pdf

https://doi.org/10.1111/chso.12012

http://www.novasmartsolutions.com.au/wp-content/uploads/2016/07/The-Invisible-Victims-of-Crime-

NOVA-Smart-Solutions.pdf 